\title{
Linkage and Association Studies between the Melanocortin Receptors 4 and 5 Genes and Obesity-Related Phenotypes in the Québec Family Study
}

\author{
Yvon C. Chagnon, ${ }^{*}$ Wen-Ji Chen, ${ }^{\dagger}$ Louis Pérusse, ${ }^{*}$ \\ Monique Chagnon,* André Nadeau, ** William O. Wilkison, ${ }^{\dagger}$ \\ and Claude Bouchard* \\ *Physical Activity Sciences Laboratory, Laval University, Ste-Foy, \\ Québec, Canada \\ †Glaxo Research Institute, Research Triangle Park, North Carolina, U.S.A. \\ **Diabetes Research Unit, Laval University Medical Center, Ste-Foy, \\ Québec, Canada
}

\begin{abstract}
Background: The agouti yellow mouse shows adult onset of moderate obesity and diabetes. A depressed basal lipolytic rate in adipocytes or a decreased adrenergic tone arising from antagonizing $\alpha$-melanocyte-stimulating hormone (MSH) activation of melanocortin receptors (MCR) could be at the origin of the obesity phenotype. Materials and Methods: MCR 4 and 5 (MC4R, MCSR) genes were studied in the Québec Family Study. Sequence variations were detected by Southern blot probing of restricted genomic DNA, and mRNA tissue expression was detected by RT-PCR. Subjects with a wide range of weight were used for single-point sib-pair linkage studies (maximum of 289 sibships from 124 nuclear families). Analysis of variance across genotypes in unrelated males $(n=143)$ and females $(n=156)$ was also undertaken. Body mass index (BMI), sum of six skinfolds (SF6), fat mass (FM), percent body fat (\%FAT),
\end{abstract}

respiratory quotient (RQ), resting metabolic rate (RMR), fasting glucose and insulin, and glucose and insulin area during an oral glucose tolerance test were analyzed. Results: $M C 4 R$ showed polymorphism with NcoI, and $M C 5 R$, with PstI and Pvull, with a heterozygosity of 0.38 , 0.10 , and 0.20 , respectively. Linkages were observed between MC5R and BMI ( $p=0.001)$, SF6 $(p=0.005)$, FM $(p=0.001)$, and RMR $(p=0.002)$, whereas associations were observed in females between MCSR and BMI ( $p=$ $0.003)$, and between MC4R and FM $(p=0.002)$ and $\%$ FAT $(p=0.004)$. After correction for multiple tests, these $p$ values are lowered by one tenth. MC4R and MC5R mRNAs have been detected in brain, adipose tissue, and skeletal muscle.

Conclusions: $M C 4 R$ and $M C 5 R$ exibit evidence of linkage or association with obesity phenotypes, but this evidence is strongest for $M C 5 R$.

\section{INTRODUCTION}

Obesity, which has become a prominent health problem in North American societies (1), has a polygenic and multifactorial origin (2). Animal

Address correspondence and reprint requests to: Dr. Claude Bouchard, Physical Activity Sciences Laboratory, Kinesiology, PEPS, Laval University, Ste-Foy, Québec G1K 7P4, Canada. Phone: 418-656-5174; Fax: 418-656-3044; e-mail: Claude.Bouchard@kin.msp.ulaval.ca models of obesity in rodents (3), such as those arising spontaneously or resulting from specific rodent crosses, could help to understand the causes of obesity. Among the single-gene mouse mutation models of obesity, the agouti yellow $\left(A^{Y}\right)$ mouse shows adult onset of moderate obesity arising from excess fat in all depots, from hyperphagia, insulin resistance, glucose intolerance, and diabetes (4). Agouti mRNA has been shown to be expressed exclusively in the skin of 
neonatal mice (5), and the ectopic expression of agouti produces the obesity phenotype (6). Moreover, it has been shown that agouti-specific expression in adipose tissue in mouse indicated obesity (7). The human homolog of agouti, renamed agouti signaling protein (ASP) gene (8), or $A S I P$, has been reported to be expressed in adipose tissue and testis (9), in heart, ovary, and, at a lower level, in liver and kidney (8). The ASIP gene has been located on human 20q11.2, but no significant linkage or association has been reported between markers in the proximity of the ASIP locus and obesity $(10,11)$.

In mice, it has been hypothesized that the effect of agouti could be mediated via the regulation of intracellular $\mathrm{Ca}^{2+}$ levels $\left(\left[\mathrm{Ca}^{2+}\right]_{\mathrm{i}}\right)$ in skeletal muscle whereby an increase in $\left[\mathrm{Ca}^{2+}\right]_{i}$ could lead to insulin resistance, hyperinsulinemia, and obesity $(12,13)$. Other mechanisms that have been proposed to explain the obesity phenotype in these mice include a depressed basal lipolytic rate in adipocytes resulting from altered intracellular cAMP levels, or a decreased adrenergic tone that may trigger hyperphagia and increased efficiency of food utilization-both mechanisms arising from antagonizing $\alpha$-melanocyte-stimulating hormone (MSH) activation of melanocortin receptors (6).

Five melanocortin receptors (MC1R to MC5R) have been identified so far in mouse and human. These receptors show various binding properties with their ligands, together with specific tissue expressions, the latter being less well characterized in humans. Agouti shifts the MSH functional curve of these receptors without affecting maximal activation, which suggests that agouti acts as a competitive antagonist inhibiting agonist binding (14). MC3R and MC5R are not antagonized by agouti in rodents (14), but human HEK-293 cells transfected with MC3R showed an increase in $\left[\mathrm{Ca}^{2+}\right]_{i}$ in the presence of agouti (15). MC4R is clearly antagonized by human agouti (14), and it has been shown that the intracerebroventricular administration of an agonist of MC4R, as well as of MC3R, inhibits feeding in four mouse models of hyperphagia, including agouti; this shows that these receptors exert a tonic inhibitory effect on feeding behavior (16). Moreover, knockout mice for $M C 4 R$ recapitulate several aspects of the agouti obesity syndrome, including hyperphagia, hyperinsulinemia, and late-onset obesity (17).

We have uncovered new restriction fragment-length polymorphisms (RFLP) for the melanocortin receptors 4 and 5, and we report here on linkage and association of these receptors with obesity-related phenotypes in subjects from the Québec Family Study (QFS). Adiposity, energy metabolism, and insulin and glucose homeostasis-related variables were analyzed. We also examined the mRNA tissue expression in humans of the MCR family genes.

\section{MATERIALS AND METHODS}

\section{Subjects and Phenotypes}

The QFS cohort has been previously described (18). Normal-weight, overweight, and obese subjects from Caucasian nuclear families of French descent from the greater Québec City area were tested for a battery of morphometric and physiologic variables. At the same time, blood samples were obtained for various assays and permanent lymphoblastoid cell lines were established for the extraction of DNA. Adiposity variables included the body mass index $(\mathrm{BMI}=$ weight in $\mathrm{kg}$ divided by height in squared meters) and the percent body fat (\%FAT), which was estimated from body density measurements obtained by underwater weighing (19) using the equation of Siri (20) with estimation of the residual pulmonary volume (21). Fat mass (FM) and fat-free mass (FFM) were obtained from percent body fat and body weight. Subcutaneous fat was estimated by the sum of six skinfold thicknesses ( $\mathrm{SF} 6=$ abdominal, subscapular, suprailiac, medial calf, triceps, and biceps). Respiratory quotient $(\mathrm{RQ})$ and resting metabolic rate (RMR) were assessed in a fasted state by indirect calorimetry over a 30 -min period using an opencircuit system with a ventilated hood, with data from the last $10 \mathrm{~min}$ being used for the calculation (22). Fasting plasma insulin (INSULIN) and glucose (GLUCOSE) levels were measured, and the total area under the curve during a $75 \mathrm{~g}$ oral glucose tolerance test (OGTT) for insulin (INSULIN AREA) and glucose (GLUCOSE AREA) was computed from the plasma levels determined at each $15 \mathrm{~min}$ for the first hour following the load and every $30 \mathrm{~min}$ for the next $2 \mathrm{hr}$, as reported earlier (23). Insulin was measured by radioimmunoassay with polyethylene glycol precipitation (24), and glucose was measured enzymatically $(25)$.

\section{DNA Polymorphism Analysis}

Genomic DNA was prepared from permanent lymphoblastoid cells by the proteinase $\mathrm{K}$ and 

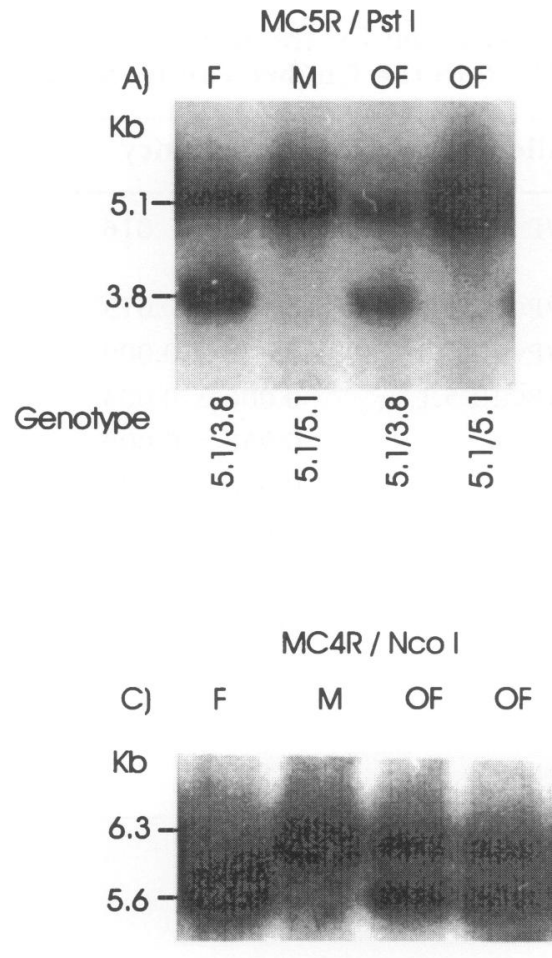

Genotype

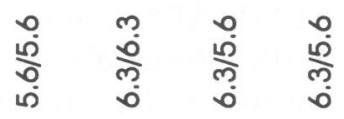

phenol/chloroform technique. DNA was dialyzed four times against TE buffer (10 mM Tris, $1 \mathrm{mM}$ EDTA, $\mathrm{pH} 8.0$ ) for $6 \mathrm{hr}$ at $4^{\circ} \mathrm{C}$ and ethanol precipitated (26). From 40 restriction enzymes tested, three-PstI, PvuII, and NcoI-showed a polymorphism with a frequency greater than $5 \%$ of variation. Five micrograms of DNA was digested 18 to $20 \mathrm{hr}$ with $50 \mathrm{U}$ of restriction enzyme PstI and PvuII for $M C 5 R$, and NcoI for $M C 4 R$, according to conditions recommended by the manufacturer (New England Biolabs, Mississauga, Ontario, Canada). Generated DNA fragments were separated on a $1.2 \%$ agarose gel by electrophoresis in $1 \times$ TAE buffer $(40 \mathrm{mM}$ Trisacetate, $1 \mathrm{mM}$ EDTA, pH 8.0) and transferred by alkali blotting in $0.25 \mathrm{M} \mathrm{NaOH}, 1.5 \mathrm{M} \mathrm{NaCl}$ (27) to nylon membrane (Hybond $\mathrm{N}+$, Amersham). DNA on the resulting Southern blot was then hybridized with the following probes. Complete coding sequences from MC4R (28) and MC5R $(29,30)$ were used as probes. cDNAs were labeled to a specific activity of $\geq 1 \times 10^{9} \mathrm{cpm} / \mu \mathrm{g}$ by random priming (T7 QuickPrime Kit, Pharmacia Biotech, Baie D'Urfé, Québec, Canada) with $\left[\alpha-{ }^{32} \mathrm{P}\right]$ dCTP (NEN DuPont Canada, Inc). Blot

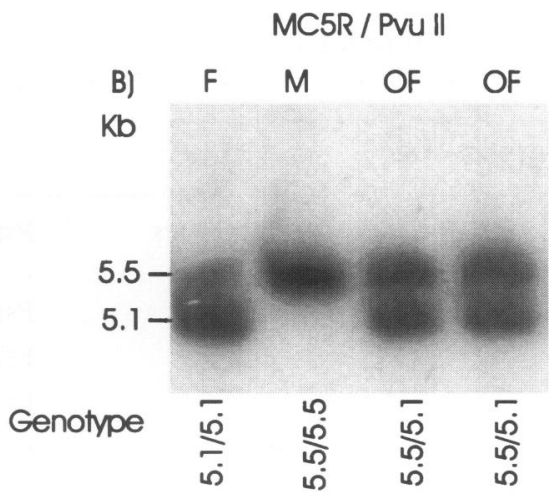

FIG. 1. Restriction fragment length polymorphism (RFLP) banding pattern of $M C 5 R(A, B)$ and $M C 4 R(C)$ restricted with different enzymes

The length in $\mathrm{kb}$ of the different alleles is given as the genotypes for the members of a family. F, father; $M$, mother; OF, offspring.

prehybridization was carried out in a hybridization oven (Robbins Scientific Corporation, Sunnyvale, CA) at $65^{\circ} \mathrm{C}$ for a minimum of $4 \mathrm{hr}$ in a solution containing $1 \mathrm{mM}$ EDTA, $0.25 \mathrm{M}$ $\mathrm{NaH}_{2} \mathrm{PO}_{4}(\mathrm{pH} 7.4), 7 \%$ sodium dodecylsulfate (SDS), and $100 \mu \mathrm{g} / \mathrm{ml}$ sonicated salmon sperm DNA. The membranes were then hybridized in fresh buffer containing the appropriate denaturated labeled probe for $18 \mathrm{hr}$ at $65^{\circ} \mathrm{C}$. They were then washed for $15 \mathrm{~min}$ three times in $0.1 \times$ SSPE $\left(20 \mathrm{mM} \mathrm{NaCl}, 1 \mathrm{mM} \mathrm{NaH} \mathrm{PO}_{4}, 0.1 \mathrm{mM}\right.$ EDTA, pH 7.7) and $0.1 \%$ SDS at $65^{\circ} \mathrm{C}$. Autoradiography was performed using Kodak XAR-5 films with intensifying screens for 3 to 5 days at $-70^{\circ} \mathrm{C}$. The size of the fragments was estimated using lambda DNA digested with HindIII and EcoRI as standards.

\section{mRNA Tissue Distribution}

Poly $\mathrm{A}^{+}$RNA of different tissues was obtained from Clontech. A first-strand cDNA was synthesized from $1 \mu \mathrm{g}$ of Poly $\mathrm{A}^{+}$RNA using a cDNA cycle kit (Invitrogen). PCR primers used for reverse transcription-polymerase chain reaction 
TABLE 1. Allele frequencies ( $\pm S E$ ) and heterozygosity observed for the four RFLPs among the melanocortin receptor 5 and 4, and the haplotype of $M C 5 R$ in the Québec Family Study

\begin{tabular}{|c|c|c|c|c|c|}
\hline Gene & Chromosome & RFLP & Allele & Frequency & Heterozygosity \\
\hline \multirow[t]{8}{*}{$M C 5 R$} & $18 \mathrm{pl} 1.2^{\mathrm{a}}$ & $\begin{array}{l}\text { Haplotypes } \\
\text { PstI/PvuII }\end{array}$ & PstI 5.1/PvuII 5.5 & $0.842 \pm 0.016$ & 0.28 \\
\hline & & & PstI 5.1/PvuII 5.1 & $0.103 \pm 0.013$ & \\
\hline & & & PstI 3.8/PvuII 5.5 & $0.049 \pm 0.009$ & \\
\hline & & & PstI 3.8/PvuII 5.1 & $0.006 \pm 0.003$ & \\
\hline & & PstI & PstI 5.1 & $0.950 \pm 0.009$ & 0.10 \\
\hline & & & PstI 3.8 & $0.050 \pm 0.009$ & \\
\hline & & PvuII & PvuII 5.5 & $0.89 \pm 0.01$ & 0.20 \\
\hline & & & PvuII 5.1 & $0.11 \pm 0.01$ & \\
\hline \multirow[t]{2}{*}{$M C 4 R$} & $18 \mathrm{q} 21.3-\mathrm{q} 22^{\mathrm{b}}$ & NcoI & NcoI 6.3 & $0.74 \pm 0.02$ & 0.38 \\
\hline & & & NcoI 5.6 & $0.26 \pm 0.02$ & \\
\hline
\end{tabular}

${ }^{a}$ ref. $35 ;{ }^{b}$ ref. 28.

(RT-PCR) of mRNA were based on the published sequences of X65634 (MClR; nucleotide [nt] 463-487; nt 1398-1421), X65635 (MC2R; nt 687-716; nt 1562-1595), L06155 (MC3R; nt 1-31; nt 1059-1083), L08603 (MC4R; nt 1-27; nt 972-999), and L27080 (MC5R; nt 430-451; nt 976-1000; nested: nt 457-480; nt 906-931). For $M C 1 R$ to $M C 4 R$, PCR was performed in a $50-\mu \mathrm{l}$ reaction containing 5 units of AmpliTaq DNA polymerase (Perkin Elmer), $2 \mathrm{mM} \mathrm{MgCl}_{2}, 0.2$ mM dNTPs, $10 \%$ glycerol, 20 pmole of primers, and one-fiftieth of the first-strand cDNA reaction as a template. The PCR amplification was performed for 35 cycles of $95^{\circ} \mathrm{C}, 30 \mathrm{sec} ; 60^{\circ} \mathrm{C}, 30 \mathrm{sec}$; $72^{\circ} \mathrm{C}, 1 \mathrm{~min}$, and one-fifth of the reaction was analyzed on a $1 \%$ agarose gel. For $M C 5 R$, the same PCR protocol was applied except that onetenth of the first-strand cDNA synthesis reaction was used as a template and a second PCR was performed using a set of nested internal primers for 20 cycles under the same amplification conditions.

\section{Statistical Analyses}

Before linkage and association analyses, the different phenotypic variables were adjusted using sex-specific regression procedures, and residuals from the regressions were used for the analyses. Insulin variables were log transformed. All variables were adjusted for age and age ${ }^{2}$, with further adjustment made for fat mass of RQ, RMR,
GLUCOSE, GLUCOSE AREA, INSULIN, and INSULIN AREA, and for fat-free mass of RQ and RMR. Residuals were then standardized to a mean 0 and a standard deviation of 1 . The single locus sib-pair linkage analysis was performed using the SIBPAL version 2.6 software from the S.A.G.E. package (31) with the $t$ statistic and the degree of freedom adjusted for the nonindependence of the sib-pairs. Association studies were undertaken by comparing mean values of the residuals across genotypes for the unrelated subjects from the parental generation using analysis of variance (ANOVA). The adjustments of the variables and the ANOVA to test for the association were performed with the SAS package (version 6.08) for PC. Probability values $(p)$ of the linkage and association tests were adjusted for multiple tests using the Bonferroni correction in which the adjusted $p$ value $p^{*}=1-(1-p)^{\text {number of traits }}(31)$.

\section{RESULTS}

The three different RFLPs observed among the two MCR genes are illustrated in Figure 1. MC5R showed two alleles with PstI (alleles 5.1 and 3.8 $\mathrm{kb}$ ) and two with PvuII (alleles 5.5 and $5.1 \mathrm{~kb}$ ) restriction enzymes. $M C 4 R$ showed polymorphism when restricted with NcoI with two generated fragments of 6.3 and $5.6 \mathrm{~kb}$, respectively. For all three polymorphisms, it is likely that the polymorphic sites are outside the coding se- 


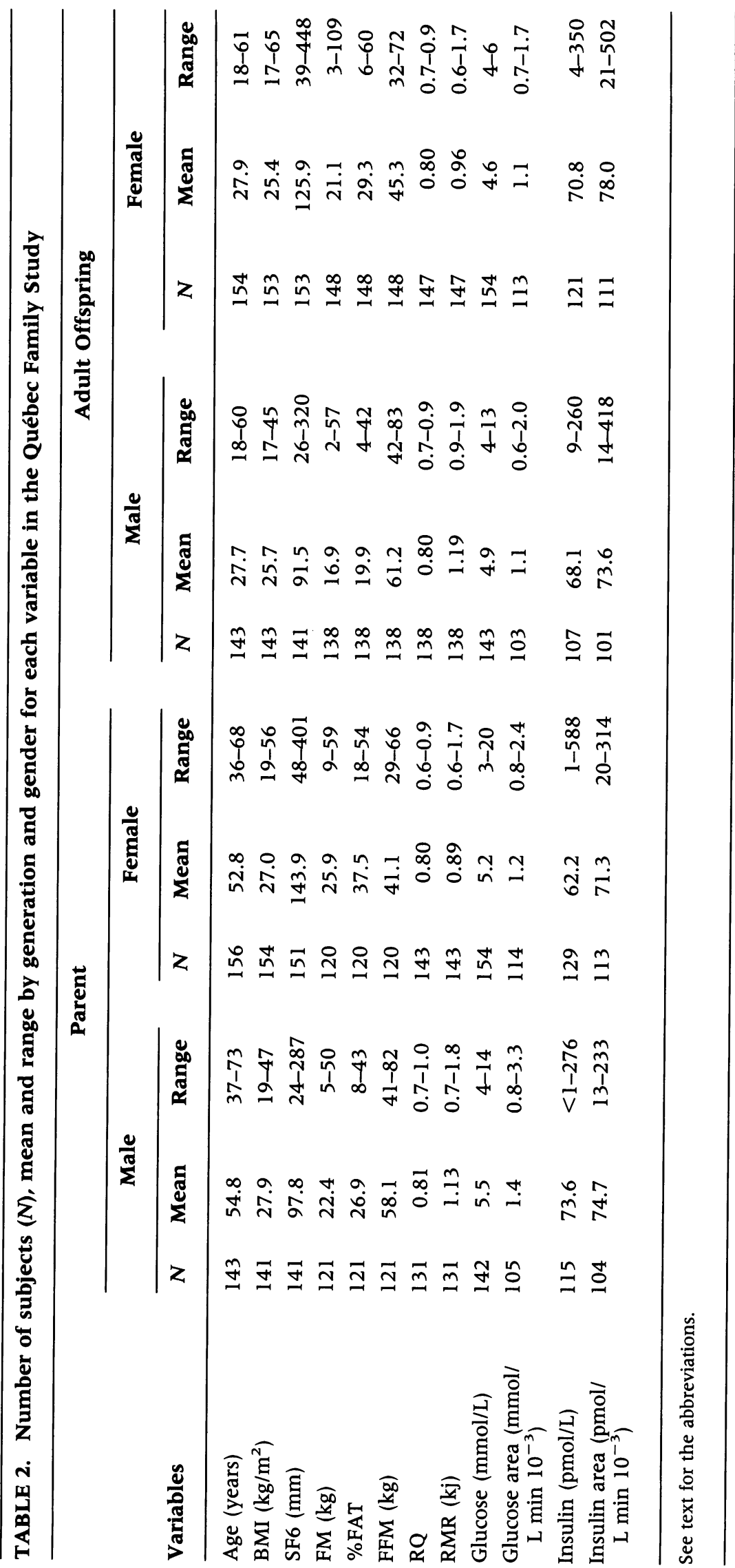


TABLE 3. Single locus sib-pair linkage results between melanocortin receptors 4 and 5 genes and obesity, and diabetes-related variables in the Québec Family Study

\begin{tabular}{|c|c|c|c|c|c|c|c|c|c|}
\hline \multirow[b]{2}{*}{ Variables } & \multicolumn{3}{|c|}{ MC5R/PstI } & \multicolumn{3}{|c|}{ MC5R/PvuII } & \multicolumn{3}{|c|}{ MC4R/NcoI } \\
\hline & $N$ & $t$ & $p$ & $N$ & $t$ & $p$ & $N$ & $t$ & $p$ \\
\hline BMI & 255 & -0.423 & 0.34 & 289 & -3.041 & $0.001^{* * *}$ & 258 & -0.037 & 0.49 \\
\hline SF6 & 253 & -0.103 & 0.46 & 287 & -2.634 & $0.005^{\star}$ & 256 & 0.166 & 0.57 \\
\hline FM & 217 & -0.306 & 0.38 & 242 & -3.145 & $0.001 * * *$ & 213 & 0.116 & 0.55 \\
\hline$\%$ FAT & 217 & -0.362 & 0.36 & 242 & -2.184 & 0.02 & 213 & 0.195 & 0.58 \\
\hline FFM & 217 & -0.955 & 0.17 & 242 & -2.423 & 0.008 & 213 & -0.443 & 0.33 \\
\hline RMR & 214 & 0.169 & 0.57 & 239 & -2.928 & $0.002^{\star \star}$ & 210 & -1.087 & 0.14 \\
\hline RQ & 214 & -0.180 & 0.43 & 239 & -0.042 & 0.48 & 210 & -1.816 & 0.04 \\
\hline Glucose & 217 & 0.888 & 0.81 & 242 & -0.107 & 0.46 & 213 & 0.586 & 0.72 \\
\hline Glucose area & 170 & 0.268 & 0.61 & 191 & -0.458 & 0.32 & 160 & 2.232 & 0.99 \\
\hline Insulin & 174 & 1.027 & 0.85 & 195 & 1.171 & 0.88 & 164 & -0.208 & 0.42 \\
\hline Insulin area & 163 & -0.584 & 0.28 & 183 & -0.375 & 0.35 & 153 & -0.724 & 0.24 \\
\hline
\end{tabular}

Significant results at $p \leq 0.05$ are highlighted in bold, and those remaining significant after the Bonferroni correction for multiple tests are indicated with asterisks. $N$, number of sib-pairs; $t, t$ statistic from the linkage regression; $p$, probability values. See text for variables abbreviations.

${ }^{*} p=0.05 ;{ }^{* *} p=0.02 ;{ }^{* *} p=0.01$.

quences. For instance, these genes are intronless and these sites have not been reported in the published sequences, except for a PstI site in $\operatorname{MC5R}(28,30,32)$. Furthermore, if the sites were located within the coding sequences, the generated restricted fragments $(0.4 \mathrm{~kb}$ for $M C 5 R$ PvuII and $0.7 \mathrm{~kb}$ for $M C 4 R \mathrm{NcoI}$ ) should be detected by the probes. On the other hand, these polymorphisms arise probably from a gain of a restriction site since the most frequent allele showed the larger DNA fragment. But an ancestral type has to be inferred from the study of other species to confirm these gains. Finally, because of the presence of the PstI site at $20 \mathrm{bp}$ of the $3^{\prime}$ end of the coding sequence, the polymorphic PstI site in $M C 5 R$ has to be located upstream or $5^{\prime}$ of the coding region, otherwise, the $3.6 \mathrm{~kb}$ allele could not be detected by the probe.

Observed allele frequencies for the three RFLPs and for the haplotype combining the two RFLPs from the MCSR gene are presented in Table 1 . Relatively low variation was observed for MC5R polymorphisms (frequencies of $95 \%$ and $89 \%$ for the most frequent alleles), which is slightly raised by using $M C 5 R$ haplotypes (frequency of $84 \%$ for the most frequent haplotype). Accordingly, the heterozygosity level for these polymorphisms was increased from 0.10 and
0.20 for PstI and PvuII individual RFLPs to 0.28 in the MC5R haplotypes. MC4R showed a slightly higher degree of variation, with the frequency of the most frequent alleles reaching 0.74 and showing a heterozygosity of 0.38 . All polymorphisms and the MC5R haplotypes are in HardyWeinberg equilibrium, and MC5R RFLPs are not in linkage disequilibrium $\left(\chi^{2}=0.44\right)$.

The mean and range of the different phenotypic variables are shown in Table 2 for each of the sex-by-generation groups. Subjects ranged in age from 18 to 73 years with a BMI from 17 to 65 $\mathrm{kg} / \mathrm{m}^{2}$. Significant correlations $(p \leq 0.05)$ were observed between all variables and age except in males with INSULIN $(p=0.15)$ and RQ $(p=$ $0.44)$, and in females with INSULIN ( $p=0.06$ ), INSULIN AREA $(p=0.68)$, and RQ $(p=0.56)$. FM and FFM contributed significantly to the variance of RMR, whereas adjustment for fatfree mass was not significant for $\mathrm{RQ}$ in both males $(p=0.15)$ and females $(p=0.07)$. In spite of these occasional nonsignificant correlations and because of borderline significance level for some variables, residuals were used for all analyses.

Table 3 shows the results of the single locus sib-pair linkage analysis between the phenotypic variables and the three polymorphisms observed 
TABLE 4. Analysis of variance (ANOVA) across genotypes for the two polymorphisms PstI and PvuII of the MC5R gene in the Québec Family Study

\begin{tabular}{|c|c|c|c|c|c|c|c|c|c|c|c|}
\hline \multirow[b]{3}{*}{ Variables } & \multirow[b]{3}{*}{ Sex } & \multicolumn{9}{|c|}{ MC5R RFLP Genotypes } & \multirow[b]{3}{*}{ ANOVA } \\
\hline & & \multicolumn{3}{|c|}{ PstI 5.1/PstI 5.1} & \multicolumn{3}{|c|}{ PstI 5.1/PstI 3.8} & \multicolumn{3}{|c|}{ PstI 3.8/PstI 3.8} & \\
\hline & & $N$ & Mean & SE & $N$ & Mean & SE & $N$ & Mean & SE & \\
\hline \multirow{2}{*}{$\begin{array}{l}\text { BMI } \\
\qquad\left(\mathrm{kg} / \mathrm{m}^{2}\right)\end{array}$} & Males & 105 & 28.1 & 0.5 & 19 & 29.0 & 1.1 & - & - & - & $p=0.71$ \\
\hline & Females & 130 & 26.5 & 0.5 & 10 & 32.2 & 1.9 & - & - & - & $p=0.003^{*}$ \\
\hline \multirow[t]{3}{*}{ SF6 $(\mathrm{mm})$} & Males & 105 & 99.8 & 3.8 & 19 & 106.8 & 9.0 & - & - & - & $p=0.74$ \\
\hline & Females & 128 & 140.5 & 4.9 & 9 & 179.1 & 18.5 & - & - & - & $p=\mathbf{0 . 0 3}$ \\
\hline & & \multicolumn{3}{|c|}{ PvuII 5.5/PvuII 5.5} & \multicolumn{3}{|c|}{ PvuII 5.5/PvuII 5.1} & \multicolumn{3}{|c|}{ PvuII 5.1/PvuII 5.1} & \\
\hline \multirow[t]{2}{*}{$\%$ FAT } & Males & 106 & 27.8 & 0.7 & 22 & 24.3 & 1.4 & 1 & 26.9 & - & $p=0.04$ \\
\hline & Females & 92 & 37.2 & 0.8 & 22 & 37.6 & 1.6 & - & - & - & $p=0.79$ \\
\hline \multirow{2}{*}{$\begin{array}{l}\text { Glucose } \\
\qquad(\mathrm{mmol} / \mathrm{L})\end{array}$} & Males & 106 & 5.5 & 0.1 & 29 & 5.7 & 0.3 & 1 & 5.7 & - & $p=0.98$ \\
\hline & Females & 120 & 5.0 & 0.2 & 28 & 5.9 & 0.3 & - & - & - & $p=\mathbf{0 . 0 3}$ \\
\hline
\end{tabular}

Only variables showing significant results at $p \leq 0.05$ (in bold) are reported. Result significant after the Bonferroni correction for multiple tests is indicated with an asterisk.

${ }^{*} p=0.03$

among the two MCR genes. The number of sibpairs used for the linkage analysis, including those from the parental generation, varied according to the combination of variable and marker analyzed. A minimum of 153 sibships from 80 nuclear families with an average sibship size of 1.9 (range 1 to 10 ) for INSULIN AREA versus MC4R/NcoI, and a maximum of 289 sibships from 124 nuclear families with an average sibship size of 2.3 (range 1 to 15 ) for BMI versus MC5R/PvuII, were used. Linkages were observed mainly for MC5R. MC5R/PvuII polymorphism showed linkages with all adiposity-related variables such as BMI, SF6, FM, and \%FAT, with $p$ values ranging from 0.001 to 0.02 , and with FFM $(p=0.008)$ and RMR $(p=0.002)$. MC5R/PstI polymorphism showed no linkage. MC4R/NcoI showed only weak linkage with RQ $(p=0.04)$. After Bonferroni correction for multiple traits tested-here, 11 traits by marker-linkages remained significant between MC5R/PvuII and BMI (corrected $p$ value $\left.p^{*}=0.01\right)$, SF6 $\left(p^{*}=\right.$ $0.05), \operatorname{FM}\left(p^{*}=0.01\right)$, and RMR $\left(p^{*}=0.02\right)$. Linkage analysis using $M C 5 R$ haplotypes (data not shown) gave positive linkages for almost the same variables as when the individual RFLPs were used (BMI: $p=0.004$; SF6: $p=0.02$; FM: $p=0.005$; \%FAT: $p=0.02$; FFM: $p=0.009$ ), except for the linkage with RMR, which was no longer significant $(p=0.10)$. Significant results, after Bonferroni correction, were observed for BMI $\left(p^{*}=0.04\right)$ and FM $\left(p^{*}=0.05\right)$. None of the three polymorphisms showed linkage with variables related to glucose and insulin metabolism (GLUCOSE, GLUCOSE AREA, INSULIN, INSULIN AREA).

Tables 4 and 5 present results of the analysis of variance across genotypes, performed on residuals. Adjusted mean values are reported only for phenotypes showing evidence of an association. MC5R/PstI (Table 4) showed significant association with BMI $\left(p=0.003 ; p^{\star}=0.03\right)$ and suggestive association with $\operatorname{SF6}(p=0.03)$ in females, but not in males. In these cases, heterozygotes PstI 5.1/PstI 3.8 showed higher mean values than those of the homozygotes for the frequent allele PstI 5.1 (BMI: $32.6 \pm 3.3$ versus $26.5 \pm 0.5$; SF6: $184.3 \pm 31.8$ versus $140.1 \pm$ 4.6). Unfortunately, no PstI 3.8 homozygote was available for this analysis. MC5R/PvuII showed no significant associations, but comparison of carriers of the less-frequent PvuII 5.1 allele and 
TABLE 5. Analysis of variance (ANOVA) across genotypes for the melanocortin receptor 4 (MC4R) NCoI RFLP in the Québec Family Study

\begin{tabular}{|c|c|c|c|c|c|c|c|c|c|c|c|}
\hline \multirow[b]{3}{*}{ Variables } & \multirow[b]{3}{*}{ Sex } & \multicolumn{9}{|c|}{ MC4R RFLP Genotypes } & \multirow[b]{3}{*}{ ANOVA } \\
\hline & & \multicolumn{3}{|c|}{ NcoI 6.3/NcoI 6.3} & \multicolumn{3}{|c|}{ NcoI 6.3/NcoI 5.6} & \multicolumn{3}{|c|}{ NcoI 5.6/NcoI 5.6} & \\
\hline & & $\boldsymbol{N}$ & Mean & SE & $\boldsymbol{N}$ & Mean & SE & $\boldsymbol{N}$ & Mean & SE & \\
\hline \multirow[t]{2}{*}{ FM $(\mathrm{kg})$} & Males & 62 & 21.4 & 1.2 & 40 & 24.4 & 1.4 & 9 & 23.1 & 3.1 & $p=0.29$ \\
\hline & Females & 60 & 23.0 & 1.3 & 40 & 30.3 & 1.6 & 3 & 28.0 & 5.7 & $p=\mathbf{0 . 0 0 2} * \star$ \\
\hline \multirow[t]{2}{*}{$\% \mathrm{FAT}$} & Males & 62 & 26.3 & 0.8 & 40 & 28.8 & 1.0 & 9 & 26.3 & 2.2 & $p=0.17$ \\
\hline & Females & 60 & 35.4 & 0.9 & 40 & 40.2 & 1.2 & 3 & 41.4 & 4.3 & $p=\mathbf{0 . 0 0 4}^{\star}$ \\
\hline \multirow[t]{2}{*}{ FFM $(\mathrm{kg})$} & Males & 62 & 57.2 & 0.9 & 40 & 58.1 & 1.2 & 9 & 62.8 & 2.4 & $p=0.14$ \\
\hline & Females & 60 & 40.4 & 0.7 & 40 & 43.0 & 0.9 & 3 & 38.4 & 3.2 & $p=0.05$ \\
\hline
\end{tabular}

Only variables showing significant results at $p \leq 0.05$ (in bold) are reported. Results remaining significant after the Bonferroni correction for multiple tests are indicated with asterisks.

${ }^{*} p=0.04 ;{ }^{* \star} p=0.02$.

noncarriers suggested associations in males for BMI $(p=0.04)$, SF6 $(p=0.05), \operatorname{FM}(p=0.04)$, and \%FAT $(p=0.02)$, with carriers showing the lowest mean for all these variables (BMI: $26.3 \pm$ 0.7 versus $28.5 \pm 0.5$; SF6: $86.3 \pm 5.4$ versus $102.9 \pm 4.2 ; \mathrm{FM}: 19.1 \pm 1.5$ versus $23.5 \pm 1.0$; \%FAT: $24.2 \pm 1.4$ versus $27.8 \pm 0.7$ ). No evidence of association was found for MC5R haplotypes (data not shown).

MC4R/NcoI (Table 5) showed significant associations with FM $\left(p^{*}=0.02\right)$ and \%FAT $\left(p^{*}=\right.$ 0.04 ) in females, with the lowest mean values observed for FM in the most frequent homozygote Ncol $6.3(23.1 \pm 1.1$ versus $30.1 \pm 1.8$ and $27.7 \pm 4.3$ ), and the highest mean value for \%FAT in the less frequent homozygote NcoI 5.6 $(42.2 \pm 5.3$ versus $39.8 \pm 1.2$ and $35.6 \pm 0.9)$. When carriers of the NcoI 5.6 allele are compared with noncarriers, significant associations are observed for FM $\left(p=0.0008 ; p^{*}=0.009\right)$ and for \%FAT $\left(p=0.004 ; p^{*}=0.04\right)$, with carriers showing higher mean values in both cases (FM: $29.9 \pm 1.7$ versus $23.1 \pm 1.1$; \%FAT: $40.0 \pm 1.2$ versus $35.6 \pm 0.9$ ).

The tissue distribution of the various MCR mRNAs by RT-PCR was also explored. For $M C 5 R$, which exhibits significant linkage with BMI, SF6, FM, and RMR, mRNA was found in adipose and brain tissues, as well as in pancreas, lung, heart and testes (Figure 2). However, this MRNA was hard to detect, as reamplification was necessary to obtain a clear signal.

In Figure 3, the distribution of the other four
MCRs is illustrated. All these receptor mRNAs were also identified in adipose tissue, in heart and testes. MCIR was expressed in pancreas, kidney, and placenta, as was $M C 2 R$, but at a lower level. Additionally, $M C 2 R$ was expressed in skeletal muscle. $M C 4 R$, which showed association with FM and \%FAT, showed a strong expression in brain and adipose tissue, with a detectable amount in skeletal muscle and liver.

\section{DISCUSSION}

After correction for multiple tests, MCSR showed significant linkages with BMI, SF6, FM, and RMR, whereas suggestive linkages were also observed with \%FAT and FFM. Similarly, significant associations were observed with BMI, whereas suggestive results were found for the other linked adiposity-related variables SF6, FM, and \%FAT. No association was observed with RMR and FFM. These results suggest that variation at the $M C 5 R$ gene could influence adiposity in humans, although it is possible that another gene in linkage disequilibrium with $M C 5 R$ could be at the origin of the observed linkages and associations. Interestingly, and according to the RFLP used, the associations appear to be sexspecific. For instance, in males, carriers of the less-frequent PvuII 5.1 allele had lower mean values for BMI, SF6, FM, and \%FAT, whereas in females, carriers of the less-frequent PstI 3.8 allele exhibited higher mean values for BMI and 


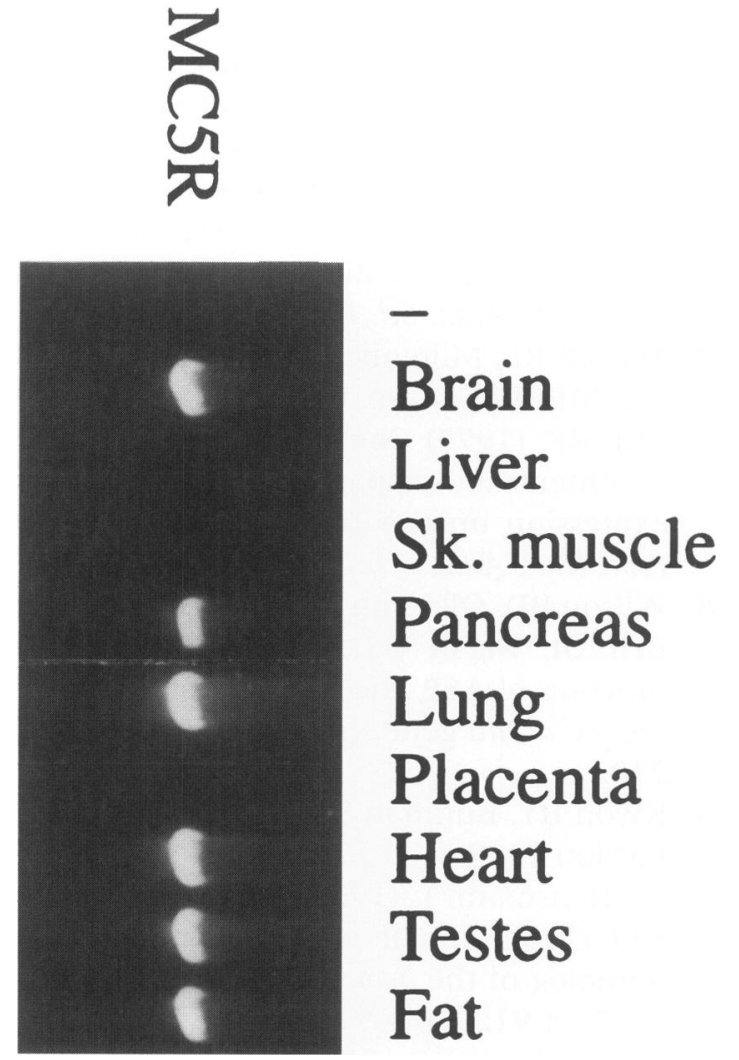

FIG. 2. Melanocortin receptor $5(M C 5 R)$ mRNA distribution in nine different human tissues

SF6. These results suggest that different alleles may have a similar effect, depending on the gender of the individual, with allele MC5R/PstI 3.8 and allele MC5R/PvuII 5.5 favoring fat accretion in females and males, respectively. It is also obvious that BMI and SF6 mean values are higher when subjects are classified according to the carrier status of the PstI polymorphism than when classified by that of PvuII, which probably reflects the gender difference effect of these alleles.

Human MC5R, as a receptor for MSH and adrenocorticotropin (ACTH), is expressed in the brain and adipose tissue, which are relevant tissues for the control of adiposity. While agouti is a weak antagonist of melanocortin peptide binding to MC5R, it is unable to stimulate $\left[\mathrm{Ca}^{+2}\right]_{\mathrm{i}}$ by this receptor. Recently it has been reported that $M C 5 R$ is also expressed in rodent adipose tissues (33), as we report here in humans. An effect of $M C 5 R$ on adiposity-related variables in humans could be expected directly at the level of the adipose tissue by a differentially modulated increase in $\left[\mathrm{Ca}^{+2}\right]_{i}$ according to the expressed $M C 5 R$ alleles. It could also be hypothesized that variation in $M C 5 R$ could modulate adrenergic
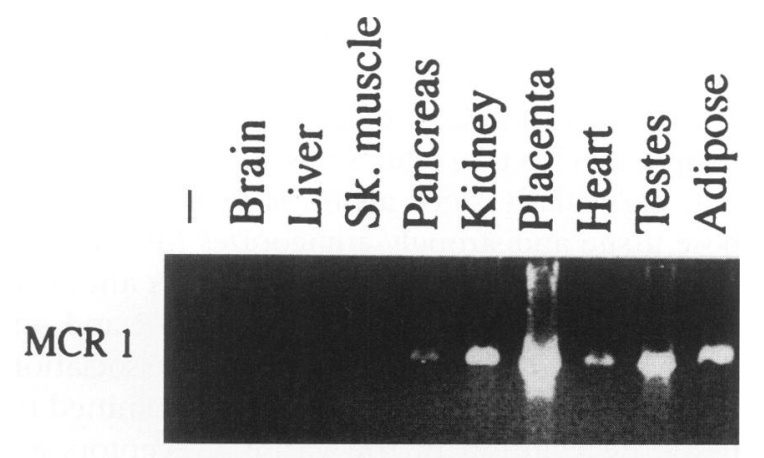

MCR 2

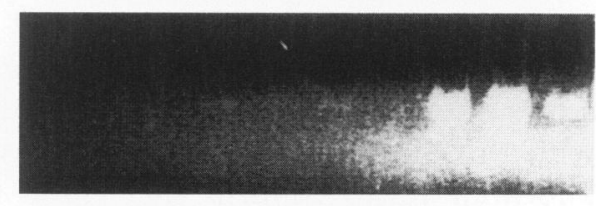

MCR 3

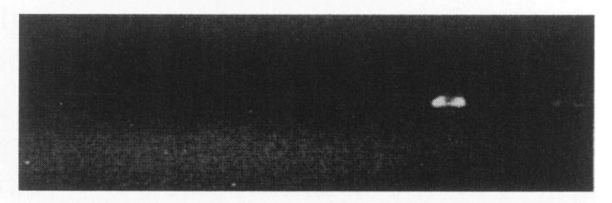

MCR 4

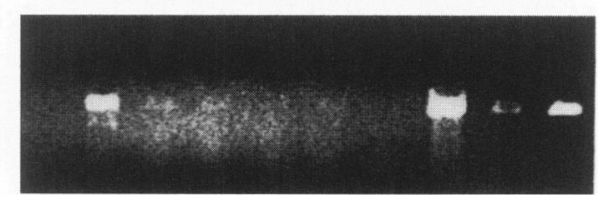

FIG. 3. Melanocortin receptors 1 to $4(M C 1 R$, $M C 2 R, M C 3 R, M C 4 R)$ mRNAs distribution in nine different human tissues

tone in brain in conjunction with other molecules, such as the recently reported agouti-related transcript or ART protein, which is expressed in the hypothalamus of both human and mouse and which showed a 10-fold increased expression in ob/ob and db/db mice (34). Additional studies in other cohorts including more subjects homozygotes for MCSR PvuII 5.1 and PstI 3.8 alleles would help to confirm and strengthen these interpretations.

$M C 4 R$ showed significant associations with FM and \%FAT in females, with significantly higher values being observed for carriers of the less-frequent NcoI 5.6 allele. In contrast to MC5R, only these two adiposity-related variables showed associations, without linkage, with $M C 4 R$, which suggests a weaker effect of MC4R on adiposity in humans. MC4R has not been observed in rodent adipose tissue (33), but our data show a clear expression of $M C 4 R$ both in brain and adipose tissue in humans (Fig. 3). Recent data showed that the knockout of this gene in mouse recapitulates several aspects of agouti obesity syndromes (17) and that intracerebroventricular administration of a specific agonist of 
MC4R inhibits feeding behavior in mouse models of hyperphagia (16). These data argue in favor of a central effect of agouti on MC4R, but a peripheral effect on adipose tissue cannot be ruled out, particularly since agouti is expressed in adipose tissue and strongly antagonizes MC4R (14).

In conclusion, significant linkages and associations were observed between MC5R and adiposity-related variables, whereas associations were observed for MC4R. We have examined the tissue distribution of the various receptors and have found that they are expressed in tissues (mainly brain, adipose, skeletal muscle) that play a role in energy balance. These results, together with those obtained recently in transgenic and knockout mice, confirm that these two MCR genes are important candidates for the obesity phenotype expression in humans. The different MCR alleles showing linkage and association in humans need to be further characterized in the search for the specific molecular variations in the MCR genes that influence body weight and fat deposition.

\section{ACKNOWLEDGMENTS}

The authors wish to acknowledge the contribution of Guy Fournier and Lucie Allard as well as Dr. Germain Thériault for the data collection in the Québec Family Study, and François Michaud and Claude Leblanc for the management of the databases. The results of this paper were obtained in part by using the program S.A.G.E., which is supported by a U.S. Public Health Service Resource grant (1P41RR03655) from the National Center for Research Resources. This research was supported by the Medical Research Council of Canada (PG-11811).

\section{REFERENCES}

1. Bray GA. (1992) Pathophysiology of obesity. Am. J. Clin. Nutr. 55: 488S-494S.

2. Bouchard C. (1994) Genetics of obesity: Overview and research directions. In: Bouchard C (ed). The Genetics of Obesity. CRC Press, Boca Raton, FL, pp. 223-233.

3. Chagnon YC, Bouchard C. (1996) The genetics of obesity: Advances from rodent studies. Trends Genet. 12: 441-444.

4. Herberg L, Coleman DL. (1977) Laboratory animals exhibiting obesity and diabetes syndromes. Metabolism 26: 59-99.
5. Bultman SJ, Michaud EJ, Woychik RP. (1992) Molecular characterization of the mouse agouti locus. Cell 71: 1195-1204.

6. Klebig ML, Wilkinson JE, Geisler JG, Woychik RP. (1995) Ectopic expression of the agouti gene in transgenic mice causes obesity, features of type II diabetes, and yellow fur. Proc. Natl. Acad. Sci. USA 92: 4728-4732.

7. Mynatt RL, Miltenberger RJ, Klebig ML, Zemel MB, Wilkinson JE, Wilkison WO, Woychik RP. (1997) Combined effects of insulin treatment and adipose tissue-specific agouti expression on the development of obesity. Proc. Natl. Acad. Sci. USA 94: 919-922.

8. Wilson BD, Ollmann MM, Kang L, Stoffel M, Bell GI, Barsh GS. (1995) Structure and function of ASP, the human homolog of the mouse agouti gene. Hum. Mol. Genet. 4: 223230.

9. Kwon HY, Bultman SJ, Löffler C, Chen W-J, Furdon PJ, Powell JG, Usala A-L, Wilkinson W, Hansmann I. (1994) Molecular structure and chromosomal mapping of the human homolog of the agouti gene. Proc. Natl. Acad. Sci. USA 91: 9760-9764.

10. Xu W, Reed DR, Ding Y, Price RA. (1995) Absence of linkage between human obesity and the mouse agouti homologous region (20q11.2) or other markers spanning chromosome 20q. Obes. Res. 3: 559-562.

11. Norman RA, Leibel RL, Chung WK, PowerKehoe L, Chua SC Jr, Knowler WC, Thompson DB, Bogardus C, Ravussin E. (1996) Absence of linkage of obesity and energy metabolism to markers flanking homologous of rodent obesity genes in Pima Indians. $\mathrm{Di}$ abetes 45: 1229-1232.

12. Zemel MB, Kim JH, Woychik RP, Michaud EJ, Kadwell SH, Patel IR, Wilkinson WO. (1995) Agouti regulation of intracellular calcium: Role in the insulin resistance of viable yellow mice. Proc. Natl. Acad. Sci. USA 92: 4733-4737.

13. Kim JH, Mynatt RL, Moore JW, Woychik RP, Moustaid N, Zemel MB. (1996) The effects of calcium channel blockade on agoutiinduced obesity. FASEB J. 10: 1646-1652.

14. Lu D, Willard D, Patel IR, Kadwell S, Overton L, Kost T, Luther M, Chen W, Woychik RP, Wilkinson WO, Cone RD. (1994) Agouti protein is an antagonist of the melanocytestimulating hormone receptor. Nature 371: 799-802.

15. Kim JH, Kiefer LL, Woychik RP, Wilkison WO, Truedale AT, Ittoop O, Willard DH, Nich- 
ols J, Zemel MB. (1997) Agouti regulation of intracellular calcium: Role of melanocortin receptors. Am. J. Physiol. 272 (Endocrinol. Metab. 35): E379-E384.

16. Fan W, Boston BA, Kesterson RA, Hruby VJ, Cone RD. (1997) Role of melanocortinergic neurons in feeding and the agouti obesity syndrome. Nature 385: 165-168.

17. Huszar D, Lynch CA, Fairchild-Huntress V, Dunmore JH, Fang Q, Berkemeier LR, Gu W, Kesterson RA, Boston BA, Cone RD, Smith FJ, Campfield LA, Burn P, Lee F. (1997) Targeted disruption of the melanocortin-4 receptor results in obesity in mice. Cell 88: 131-141.

18. Bouchard C. (1996) Genetic epidemiology, association and sib-pair linkage: Results from The Québec Family Study. In: Bray GA, Ryan DH (eds). Molecular and Genetic Aspects of Obesity. Louisiana State University Press, Baton Rouge, pp. 470-481.

19. Behnke AR, Wilmore JH. (1974) Evaluation and Regulation of Body Build and Composition. Prentice-Hall, Englewood Cliffs, NJ

20. Siri WE. (1976) The gross composition of the body. Adv. Biol. Med. Phys. 4: 239-280.

21. Himes JH, Bouchard C. (1989) Validity of anthropometry in classifying youths as obese. Int. J. Obes. 13: 183-193.

22. Dériaz O, Dionne F, Pérusse L, Tremblay A, Vohl M-C, Côté G, Bouchard C. (1994) DNA variation in the genes of the $\mathrm{Na}, \mathrm{K}$-adenosine triphosphatase and its relation with resting metabolic rate, respiratory quotient, and body fat. J. Clin. Invest. 93: 838-843.

23. Oppert JM, Nadeau A, Tremblay A, Després JP, Thériault G, Dériaz O, Bouchard C. (1995) Plasma glucose, insulin, and glucagon before and after long-term overfeeding in identical twins. Metabolism 44: 96-105.

24. Desbuquois B, Aurbach GD. (1971) Use of polyethylene glycol to separate free and antibody-bound peptide hormone in radioimmunoassays. J. Clin. Endocrinol. Metab. 37: 732-738.

25. Richterich R, Dauwalder H. (1971) Determination of plasma glucose concentration by the hexokinase-glucose-6-phosphate-dehydrogenase method (in German). Schweiz. Med. Wochenschr. 101: 601-618.
26. Sambrook J, Fritsch EF, Maniatis T. (1989) Molecular Cloning. A Laboratory Manual, 2nd ed., Cold Spring Harbor Laboratory Press, Cold Spring Harbor, NY, pp. 9.16-9.19.

27. Reed KC, Mann DA. (1985) Rapid transfer of DNA from agarose gels to nylon membranes. Nucl. Acids Res. 13: 7207-7221.

28. Gantz I, Miwa H, Konda Y, Shimoto Y, Tashiro T, Waston SJ, DelValle J. (1993) Molecular cloning, expression, and gene localization of a fourth melanocortin receptor. J. Biol. Chem. 268: 15174-15179.

29. Chhajlani V, Muceniece R, Wikberg JE. (1993) Molecular cloning of a novel human melanocortin receptor. Biochem. Biophys. Res. Commun. 195: 866-873.

30. Gantz I, Shimoto Y, Konda Y, Miwa H, Dickinson CJ, Yamada T. (1994) Molecular cloning, expression, and characterization of a fifth melanocortin receptor. Biochem. Biophys. Res. Commun. 200: 1214-1220.

31. S.A.G.E. (1994) Statistical Analysis for Genetic Epidemiology, release 2.2. Computer program package available from the Department of Biometry and Genetics, LSU Medical Center, New Orleans, LA.

32. Gantz I, Tashiro T, Barcroft C, Konda Y, Shimoto Y, Miwa H, Glover T, Munzert G, Yamada T. (1993) Localization of the genes encoding the melanocortin-2 (adrenocorticotropic hormone) and melanocortin-3 receptors to chromosomes $18 \mathrm{p} 11.2$ and 20q13.2-q13.3 by fluorescence in situ hybridization. Genomics 18: 166-167.

33. Boston BA, Cone RD. (1996) Characterization of melanocortin receptor subtype expression in murine adipose tissues and in the 3T3-Ll cell line. Endocrinology 137: 20432050.

34. Shutter JR, Graham M, Kinsey AC, Scully S, Lüthy R, Stark KL. (1997) Hypothalamic expression of ART, a novel gene related to agouti, is up-regulated in obese and diabetic mutant mice. Genes Dev. 11: 593-602.

35. Chowdhary BP, Gustavsson I, Wikberg JE, Chhajlani V. (1995) Localization of the human melanocortin-5 receptor gene (MCSR) to chromosome band $18 \mathrm{pl} 1.2$ by fluorescence in situ hybridization. Cytogenet. Cell. Genet. 68: 79-81.

Communicated by D. F. Steiner. Accepted July 23, 1997. 